\title{
Pengaruh Disiplin dan Iklim Kerja terhadap Kinerja Kepala Sekolah pada Sekolah Menengah Kejuruan Muhammadiyah Cipulir, Jakarta Selatan
}

\section{The Influence of Discipline and Work Climate on The Performance of School Heads in Muhammadiyah Vocational School, Cipulir, Jakarta Selatan}

\section{Hendrian Yonata ${ }^{1}$, Hadion Wijoyo ${ }^{2}$, \& Denok Sunarsi ${ }^{3}$}

1) Sekolah Tinggi Agama Buddha Dharma Widya, Indonesia 2) Sekolah Tinggi Manajemen Informatika Komputer Dharmapala, Indonesia

3) Universitas Pamulang, Indonesia

Diterima: 01 Oktober 2020; Direview: 11 Oktober 2020; Disetujui: 18 Oktober 2020

*Coresponding Email : hadion.wijoyo@lecturer.stmikdharmapalariau.ac.id2,denoksunarsi@unpam.ac.id3

\section{Abstrak}

Penelitian ini bertujuan untuk mengetahui pengaruh disiplin dan iklim kerja terhadap kinerja kepala sekolah pada Sekolah Menengah Kejuruan Muhammadiyah Cipulir, Jakarta Selatan. Metode yang digunakan adalah explanatory research dengan teknik analisis menggunakan analisis statistik dengan pengujian regresi, korelasi, determinasi dan uji hipotesis. Hasil penelitian ini disiplin berpengaruh signifikan terhadap kinerja kepala sekolah sebesar 51,9\%, uji hipotesis diperoleh $\mathrm{t}$ hitung $>\mathrm{t}$ tabel atau $(7,568>2,006)$. Iklim kerja berpengaruh signifikan terhadap kinerja kepala sekolah sebesar 44,0\%, uji hipotesis diperoleh $t$ hitung $>t$ tabel atau $(6,456>2,006)$. Disiplin dan iklim kerja secara simultan berpengaruh signifikan terhadap kinerja kepala sekolah dengan persamaan regresi Y $=7,924+0,419 X 1$ $+0,387 \mathrm{X} 2$ dan kontribusi pengaruh sebesar $61,6 \%$, uji hipotesis diperoleh F hitung $>\mathrm{F}$ tabel atau $(41,741$ $>2,780$ ).

Kata Kunci: Disiplin, Iklim Kerja, Kinerja Kepala Sekolah.

\section{Abstract}

This study aims to determine the effect of discipline and work climate on the performance of school principals at Cipulir Muhammadiyah Vocational High School, South Jakarta. The method used is explanatory research with analysis techniques using statistical analysis with regression testing, correlation, determination and hypothesis testing. The results of this study, the discipline has a significant effect on the performance of the principal by 51.9\%, the hypothesis test is obtained $t$ count $t$ table or (7.568> 2.006). Work climate has a significant effect on the performance of school principals by $44.0 \%$, hypothesis testing is obtained $t$ count $>t$ table or (6.456> 2.006). Discipline and work climate simultaneously have a significant effect on the performance of school principals with the regression equation $Y=7.924+0.419 X 1+0.387 X 2$ and the influence contribution is 61.6\%, the hypothesis test obtained F count $>$ F table or (41.741>2.780). Keywords: Discipline, Work climate, Principal Performance.

How to Cite: Yonata, H. Wijoyo, H. \& Sunarsi, D. (2020). Pengaruh Disiplin dan Iklim Kerja Terhadap Kinerja Kepala Sekolah Pada Sekolah Menengah Kejuruan Muhammadiyah Cipulir, Jakarta Selatan. Journal of Education, Humaniora and Social Sciences (JEHSS). 3(2): 594-600. 


\section{PENDAHULUAN}

Kepemimpinan seorang kepala sekolah sangat penting dalam menjalankan jalannya proses pembelajaran yang maksimal. Kinerja (performance) dapat diartikan sebagai tingkat pelaksanaan tugas yang dapat dicapai seseorang dengan menggunakan kemampuan yang ada dan batasanbatasan yang telah ditetapkan untuk mencapai tujuan organisasi dalam hal ini sekolah, (Wijoyo, 2009) Hal tersebut sesuai dengan pendapat Wahyuningtyas \& Utami (2018) yang menyatakan bahwa kinerja merupakan suatu persyaratan tertentu yang akhirnya secara langsung dapat tercermin dari output yang dihasilkan baik yang berupa jumlah maupun kualitasnya. Output yang dihasilkan dapat berupa fisik maupun non fisik yang menyebutkan berupa karya (Latief et al., 2019; Latief, et al., 2019; Haryati, et al., 2019).

Seorang kepala sekolah dalam mengerjakan tugasnya dengan baik, sering kali ditentukan oleh penilaian terhadap kinerjanya. Penilaian tidak hanya dilakukan untuk membantu mengawasi sumberdaya namun untuk mengukur tingkat efisiensi penggunaan sumber daya yang ada dan meng- identifikasi hal-hal yang perlu di- perbaiki. Penilaian terhadap prestasi kerja merupakan faktor penting untuk meningkatkan kinerja dan kepuasan kerja kepala sekolah, bagian-bagian yang menunjukkan kemampuan kepala sekolah yang kurang dapat diidentifikasi, diketahui sehingga dapat ditentukan strategi dalam meningkatkan kinerjanya.

Kepala sekolah merupakan faktor sentral di dalam sistem pembelajaran terutama di sekolah. Peranan kepala sekolah sangat penting dalam mentransformasikan input-input pendidikan, sehingga dapat dipastikan bahwa di sekolah tidak akan ada perubahan atau peningkatan kualitas tanpa adanya perubahan dan peningkatan kualitas kepala sekolah. Hal ini berarti, pendidikan yang baik dan unggul tetap akan bergantung pada kondisi mutu kepala sekolah. UNESCO menyatakan bahwa "mem- perbaiki mutu pendidikan pertama-tama tergantung pada perbaikan perekrutan, pelatihan, status sosial, dan kondisi para kepala sekolah; mereka membutuhkan pengetahuan dan keterampilan, karakter personal, prospek professional, dan motivasi yang tepat jika ingin memenuhi harapan stakeholder" (Soepeno et al., 2015)

Kualitas kepala sekolah akan mempengaruhi keberhasilan siswa dalam belajar, yang berujung pada peningkatan mutu pendidikan, untuk itu kepala sekolah dituntut untuk lebih professional dalam men- jalankan tugasnya. Tugas keprofesi- onalan kepala sekolah menurut Undang-undang Republik Indonesia Nomor 14 tahun 2005 pasal 20 (a) tentang kepala sekolah dan dosen adalah merencanakan pembelajaran, melaksanakan proses pembelajaran yang bermutu, serta menilai dan mengevaluasi hasil pembelajaran. Tugas pokok kepala sekolah tersebut yang diwujudkan dalam kegiatan pembelajaran serta tugas-tugas kepala sekolah dalam kelembagaan merupakan bentuk kinerja kepala sekolah. Kinerja kepala sekolah akan baik jika kepala sekolah telah melaksanakan unsur- unsur yang terdiri dari kesetiaan dan komitmen yang tinggi pada tugas mengajar, menguasai dan mengem- bangkan bahan pelajaran, kedisiplinan dalam mengajar, dan tugas lainnya, kreativitas dalam pelaksanaan peng- ajaran, kerjasama dengan semua warga sekolah, pemimpin yang menjadi panutan siswa, kepribadian yang baik, jujur dan obyektif dalam membimbing siswa, serta tanggung jawab atas tugasnya.

Apabila kinerja kepala sekolah meningkat maka akan berpengaruh pada kualitas outputnya, oleh sebab itu perlu dukungan dari berbagai pihak sekolah untuk meningkatkan kinerja kepala sekolah. Kepala sekolah selaku pimpinan tertinggi di sekolah dianggap berhasil jika dapat meningkatkan kinerja kepala sekolah melalui berbagai macam bentuk kegiatan pembinaan terhadap kemampuan kepala sekolah dalam melaksanakan pembelajaran di sekolah. Untuk itu kepala sekolah harus mampu menjalankan peran dan tanggung jawabnya sebagai seorang manajer pendidikan, pemimpin pendidikan, supervisor pendidikan, administrator pendidikan, pembinaan tenaga kepen- didikan lainnya dan pendayagunaan serta pemeliharaan sarana dan prasarana (Andrianto \& Wijoyo, 2020) Kepala sekolah diharapkan mampu menciptakan suasana kerja yang nyaman dan kondusif di sekolah, sehingga setiap kepala sekolah dapat bekerja dengan maksimal sehingga kinerja kerja dapat tercapai. Ada beberapa faktor penting yang berpengaruh terhadap me- ningkatnya kinerja kepala sekolah, yaitu disiplin kerja kepala sekolah. Disiplin kerja sering terabaikan dikalangan kepala sekolah. Hal ini dapat dilihat dari beberapa contoh antara lain: 
datang ke sekolah terlambat, tidak berada di sekolah pada jam kerja, menunda pekerjaan, pulang sebelum waktunya dan lain-lain. Bagi mereka yang terpenting adalah mengisi daftar hadir. Hal demikian ini secara tidak langsung akan mempengaruhi prestasi sekolah.

Menurut Hadiyanto (2014)(Sunarsi et al., 2020) iklim kerja sekolah adalah situasi atau suasana yang muncul karena adanya hubungan antara kepala sekolah dan guru, kepala sekolah dengan sataf, kepala sekolah dengan peserta didik atau hubungan antara peserta didik yang menjadi ciri khas sekolah yang ikut mempengaruhi proses belajar mengajar di sekolah. Iklim kerja sekolah merupakan perasaan pribadi tentang pengalaman kepala sekolah terhadap situasi dan kundisi lingkungan sekolah yang nyaman dan mendukung untuk kegiatan belajar dan mengajar, bimbingan keteraturan dan keamanan yang dirasakan oleh setiap personel sekolah (Suci et al., 2020). Iklim sekolah juga mencakup sejumlah variabel yang dipersepsikan oleh siswa, teman-teman seprofesi, kepala sekolah, pegawai tata usaha, dan personel lainnya serta kepedulian orang tua terhadap sekolah. Selain itu iklim sekolah juga mencakup perasaan kepala sekolah sebagai bagian dari sekolah dan perasaan memiliki sekolah. Iklim sekolah juga menyangkut norma-norma yang berlaku dan harapan yang dipegang dan dikomunikasikan oleh anggota sekolah.

Iklim sekolah yang kondusif akan berdampak pada kinerja kepala sekolah. Terciptanya iklim sekolah yang kondusif, maka kepala sekolah akan menjadi nyaman dalam bekerja dan terpacu untuk bekerja lebih baik lagi. Hal tersebut mencerminkan bahwa suasana sekolah yang kondusif sangat mendukung peningkatan kinerja kepala sekolah. Budaya dan iklim sekolah yang kondusif akan memungkinkan setiap kepala sekolah untuk menunjukkan kinerjanya secara unggul, yang disertai usaha untuk meningkatkan kompetensinya (Philipus, 2009).

Penulis mencoba mengkaji fenomena yang terjadi pada kepala sekolah-kepala sekolah Sekolah Menengah Kejuruan Muhammadiyah Cipulir, bahwa terdapat kecendrungan melemahnya kinerja kepala sekolah antara lain belum menerapkan strategi belajar yang bervariasi, belum menerapkan struktur kegiatan pembelajaran yang efektif, belum memperbaiki kinerja mengajar melalui penelitian PTK, serta dalam mengembangkan silabus belum melakukan analisa konteks (Agusta \& Sutanto, 2013). Berdasarkan uraian-uraian di atas, penulis menganggap perlu untuk melakukan penelitian yang berjudul, "pengaruh disiplin kerja dan iklim kerja terhadap kinerja kepala Sekolah Menengah Kejuruan Muhammadiyah Cipulir, Jakarta.

\section{METODE PENELITIAN}

Populasi dalam penelitian ini berjumlah 55 responden Sekolah Menengah Kejuruan Muhammadiyah Cipulir, Jakarta Selatan. Sampel dalam penelitian ini berjumlah 55 responden. Jenis penelitian yang dipakai adalah asosiatif, dimana tujuannya adalah untuk mengetahui pengaruh antara variabel bebas terhadap variabel terikat baik parsial maupun simultan. Dalam menganalisis data digunakan uji instrumen, uji asumsi klasik, regresi, koefisien determinasi dan uji hipotesis.

\section{HASIL DAN PEMBAHASAN \\ Analisis Deskriptif}

Pada pengujian ini digunakan untuk mengetahui skor minimum dan maksimum, mean score dan standar deviasi dari masing-masing variabel. Adapun hasilnya sebagai berikut:

Tabel Hasil Analisis Descriptive Statistics

Descriptive Statistics

\begin{tabular}{llllll} 
& $\mathrm{N}$ & Minimum & Maximum & Mean & Std. Deviation \\
\hline Disiplin (X1) & 55 & 31 & 48 & 37.16 & 4.438 \\
\hline Iklim kerja (X2) & 55 & 28 & 48 & 37.49 & 3.569 \\
\hline Kinerja Kepala sekolah (Y) & 55 & 32 & 48 & 38.02 & 3.664 \\
\hline Valid N (listwise) & 55 & & & &
\end{tabular}

Disiplin diperoleh varians minimum sebesar 31 dan varians maximum 48 dengan mean score sebesar 37,16 dengan standar deviasi 4,439. 
Iklim kerja diperoleh varians minimum sebesar 28 dan varians maximum 48 dengan mean score sebesar 37,49 dengan standar deviasi 3,569.

Kinerja kepala sekolah diperoleh varians minimum sebesar 32 dan varians maximum 48 dengan mean score sebesar 38,02 dengan standar deviasi 3,664.

\section{Analisis Verifikatif.}

Pada analisis ini dimaksudkan untuk mengetahui pengaruh variabel independen terhadap variabel dependen. Adapun hasil pengujian sebagai berikut:

\section{a. Analisis Regresi Linier Berganda}

Uji regresi ini dimaksudkan untuk mengetahui perubahan variabel dependen jika variabel independen mengalami perubahan. Adapun hasil pengujiannya sebagai berikut:

Tabel Hasil Pengujian Regresi Linier Berganda

\begin{tabular}{|c|c|c|c|c|c|c|}
\hline \multicolumn{2}{|c|}{ Model } & \multicolumn{2}{|c|}{$\begin{array}{c}\text { Coefficients }^{\mathrm{a}} \\
\text { Unstandardized Coefficients Standardized Coefficients }\end{array}$} & $\begin{array}{l}\mathrm{s}^{\mathrm{a}} \\
\text { Standardized Coefficients } \\
\text { Beta }\end{array}$ & $\mathrm{t}$ & Sig. \\
\hline 1 & (Constant) & 7.924 & 3.450 & & 2.297 & .026 \\
\hline & Disiplin $\left(\mathrm{X}_{1}\right)$ & .419 & .086 & .508 & 4.882 & .000 \\
\hline & Iklim kerja (X2) & .387 & .107 & .377 & 3.621 & .001 \\
\hline
\end{tabular}

a. Dependent Variable: Kinerja Kepala sekolah (Y)

Berdasarkan hasil pengujian pada tabel di atas, diperoleh persamaan regresi $Y=7,924+$ 0,419X1 + 0,387X2. Dari persamaan tersebut dijelaskan sebagai berikut:

1) Konstanta sebesar 7,924 diartikan jika disiplin dan iklim kerja tidak ada, maka telah terdapat nilai kinerja kepala sekolah sebesar 7,924 point.

2) Koefisien regresi disiplin sebesar 0,419 , angka ini positif artinya setiap ada peningkatan disiplin sebesar 0,419 maka kinerja kepala sekolah juga akan mengalami peningkatan sebesar 0,419 point.

3) Koefisien regresi iklim kerja sebesar 0,387, angka ini positif artinya setiap ada peningkatan iklim kerja sebesar 0,387 maka kinerja kepala sekolah juga akan mengalami peningkatan sebesar 0,387 point.

\section{b. Analisis Koefisien Korelasi}

Analisis koefisien korelasi dimaksudkan untuk mengetahui tingkt kekuatan hubungan dari variabel independen terhadap variabel dependen baik secara parsial maupun simultan. Adapun hasil pengujian sebagai berikut:

Tabel Hasil Pengujian Koefisien Korelasi Disiplin Terhadap Kinerja Kepala sekolah. Correlations ${ }^{\mathrm{b}}$

\begin{tabular}{llll} 
& & Disiplin $\left(\mathrm{X}_{1}\right)$ & Kinerja Kepala sekolah $(\mathrm{Y})$ \\
\hline Disiplin $\left(\mathrm{X}_{1}\right)$ & Pearson Correlation & 1 & $.721^{* *}$ \\
\cline { 2 - 4 } & Sig. (2-tailed) & & .000 \\
\hline Kinerja Kepala sekolah $(\mathrm{Y})$ & Pearson Correlation & $.721^{* *}$ & 1 \\
\cline { 2 - 4 } & Sig. (2-tailed) & .000 & \\
\hline
\end{tabular}

Berdasarkan hasil pengujian diperoleh nilai korelasi sebesar 0,721 artinya disiplin memiliki hubungan yang kuat terhadap kinerja kepala sekolah.

Tabel Hasil Pengujian Koefisien Korelasi Iklim kerja Terhadap Kinerja Kepala sekolah. Correlations $^{\mathrm{b}}$

\begin{tabular}{llll} 
& & Iklim kerja $\left(\mathrm{X}_{2}\right)$ & Kinerja Kepala sekolah $(\mathrm{Y})$ \\
\hline Iklim kerja (X2) & Pearson Correlation & 1 & $.663^{* *}$ \\
\cline { 2 - 4 } & Sig. (2-tailed) & & .000 \\
\hline \multirow{2}{*}{ Kinerja Kepala sekolah (Y) Pearson Correlation } & $.663^{* *}$ & 1 \\
\cline { 2 - 4 } & Sig. (2-tailed) & .000 & \\
\hline
\end{tabular}

Berdasarkan hasil pengujian diperoleh nilai korelasi sebesar 0,663 artinya iklim kerja memiliki hubungan yang kuat terhadap kinerja kepala sekolah. 
Hendrian Yonata, Hadion Wijoyo, \& Denok Sunarsi, Pengaruh Disiplin dan Iklim Kerja Terhadap Kinerja

Tabel Hasil Pengujian Koefisien Korelasi Disiplin dan Iklim kerja secara simultan Terhadap Kinerja Kepala sekolah.

Model Summary

\begin{tabular}{lllll} 
Model & R & R Square & Adjusted R Square & Std. Error of the Estimate \\
\hline 1 & $.785^{\mathrm{a}}$ & .616 & .601 & 2.313 \\
\hline
\end{tabular}

a. Predictors: (Constant), Iklim kerja (X2), Disiplin (X1)

Berdasarkan hasil pengujian diperoleh nilai korelasi sebesar 0,785 artinya disiplin dan iklim kerja secara simultan memiliki hubungan yang kuat terhadap kinerja kepala sekolah.

\section{c. Analisis Koefisien Determinasi}

Analisis koefisien determinasi dimaksudkan untuk mengetahui besarnya persentase pengaruh dari variabel independen terhadap variabel dependen baik secara parsial maupun simultan. Adapun hasil pengujian sebagai berikut:

Tabel Hasil Pengujian Koefisien Determinasi Disiplin Terhadap Kinerja Kepala sekolah.

\begin{tabular}{lllll} 
& \multicolumn{3}{c}{ Model Summary } \\
Model & $\mathrm{R}$ & R Square & Adjusted R Square & Std. Error of the Estimate \\
\hline $\mathbf{1}$ & $.721^{\mathrm{a}}$ & .519 & .510 & 2.564 \\
\hline
\end{tabular}

a. Predictors: (Constant), Disiplin ( $\left.\mathrm{X}_{1}\right)$

Berdasarkan hasil pengujian diperoleh nilai determinasi sebesar 0,519 artinya disiplin memiliki kontribusi pengaruh sebesar 51,9\% terhadap kinerja kepala sekolah.

Tabel 7. Hasil Pengujian Koefisien Determinasi Iklim kerja Terhadap Kinerja Kepala sekolah.

\begin{tabular}{lllll} 
& \multicolumn{3}{c}{ Model Summary } \\
Model & R & R Square & Adjusted R Square & Std. Error of the Estimate \\
\hline 1 & $.663^{\mathrm{a}}$ & .440 & .430 & 2.767 \\
\hline
\end{tabular}

a. Predictors: (Constant), Iklim kerja (X2)

Berdasarkan hasil pengujian diperoleh nilai determinasi sebesar 0,440 artinya iklim kerja memiliki kontribusi pengaruh sebesar 44,0\% terhadap kinerja kepala sekolah.

Tabel Hasil Pengujian Koefisien Determinasi Disiplin dan Iklim kerja Terhadap Kinerja Kepala sekolah. Model Summary

\begin{tabular}{lllll} 
Model & $\mathrm{R}$ & R Square & Adjusted R Square & Std. Error of the Estimate \\
\hline 1 & $.785^{\mathrm{a}}$ & .616 & .601 & 2.313 \\
\hline
\end{tabular}

a. Predictors: (Constant), Iklim kerja (X2), Disiplin (X1)

Berdasarkan hasil pengujian diperoleh nilai determinasi sebesar 0,616 artinya disiplin dan iklim kerja secara simultan memiliki kontribusi pengaruh sebesar $61,6 \%$ terhadap kinerja kepala sekolah, sedangkan sisanya sebesar 38,4\% dipengaruhi faktor lain.

\section{d. Uji Hipotesis}

\section{Uji hipotesis Parsial (Uji t)}

Pengujian hipotesis dengan uji t digunakan untuk mengetahui hipotesis parsial mana yang diterima. Hipotesis pertama: Terdapat pengaruh yang signifikan antara disiplin terhadap kinerja kepala sekolah.

Tabel Hasil Uji Hipotesis Disiplin Terhadap Kinerja Kepala sekolah.

$$
\text { Coefficients }^{a}
$$

Unstandardized Coefficients Standardized Coefficients

\begin{tabular}{|c|c|c|c|c|c|c|}
\hline \multicolumn{2}{|c|}{ Model } & \multirow{2}{*}{$\frac{B}{15.905}$} & \multirow{2}{*}{$\begin{array}{l}\text { Std. Error } \\
2.942\end{array}$} & \multirow[t]{2}{*}{ Beta } & \multirow{2}{*}{$\frac{t}{5.406}$} & \multirow{2}{*}{$\frac{\text { Sig. }}{.000}$} \\
\hline 1 & (Constant) & & & & & \\
\hline & Disiplin (X1) & .595 & .079 & .721 & $7 \cdot 568$ & .000 \\
\hline
\end{tabular}


a. Dependent Variable: Kinerja Kepala sekolah (Y)

Berdasarkan hasil pengujian pada tabel di atas, diperoleh nilai t hitung $>\mathrm{t}$ tabel atau $(7,568$ $>2,006)$, dengan demikian hipotesis pertama yang diajukan bahwa terdapat pengaruh yang signifikan atara disiplin terhadap kinerja kepala sekolah diterima.

Tabel Hasil Uji Hipotesis Iklim kerja Terhadap Kinerja Kepala sekolah. Coefficients ${ }^{\mathrm{a}}$

\begin{tabular}{|c|c|c|c|c|c|c|}
\hline \multirow{2}{*}{\multicolumn{2}{|c|}{ Model }} & \multicolumn{2}{|c|}{ Unstandardized Coefficients } & \multirow{2}{*}{$\begin{array}{l}\text { Standardized Coefficients } \\
\text { Beta }\end{array}$} & \multirow[b]{2}{*}{$t$} & \multirow[b]{2}{*}{ Sig. } \\
\hline & & $\mathrm{B}$ & Std. Error & & & \\
\hline 1 & (Constant) & 12.478 & $3 \cdot 973$ & & 3.140 & .003 \\
\hline & Iklim kerja (X2) & .681 & .106 & .663 & 6.456 & .000 \\
\hline
\end{tabular}

a. Dependent Variable: Kinerja Kepala sekolah (Y)

Berdasarkan hasil pengujian pada tabel di atas, diperoleh nilai t hitung $>\mathrm{t}$ tabel atau $(6,456$ $>2,006)$, dengan demikian hipotesis kedua yang diajukan bahwa terdapat pengaruh yang signifikan atara iklim kerja terhadap kinerja kepala sekolah diterima.

\section{Uji Hipotesis Simultan (Uji F)}

Pengujian hipotesis dengan uji F digunakan untuk mengetahui hipotesis simultan yang mana yang diterima. Hipotesis ketiga Terdapat pengaruh yang signifikan antara disiplin dan iklim kerja terhadap kinerja kepala sekolah.

Tabel Hasil Uji Hipotesis Disiplin dan Iklim kerja Terhadap Kinerja Kepala sekolah.

$$
\text { ANOVA }^{a}
$$

\begin{tabular}{llllllll} 
Model & & Sum of Squares & df & Mean Square & F & Sig. \\
\hline 1 & Regression & 446.722 & 2 & 223.361 & 41.741 &. .0oo $^{\mathrm{b}}$ \\
\cline { 2 - 6 } & Residual & $\mathbf{2 7 8 . 2 6 0}$ & 52 & 5.351 & & \\
\cline { 2 - 4 } & 724.982 & 54 & & & \\
\hline
\end{tabular}

Berdasarkan hasil pengujian pada tabel di atas, diperoleh nilai $\mathrm{F}$ hitung $>\mathrm{F}$ tabel atau $(41,741$ $>2,780$ ), dengan demikian hipotesis ketiga yang diajukan bahwa terdapat pengaruh yang signifikan atara disiplin dan iklim kerja terhadap kinerja kepala sekolah diterima.

\section{Pengaruh Disiplin Terhadap Kinerja Kepala sekolah}

Disiplin berpengaruh signifikan terhadap kinerja kepala sekolah dengan korelasi sebesar 0,721 atau memiliki hubungan yang kuat dengan kontribusi pengaruh sebesar 51,9\%. Pengujian hipotesis diperoleh nilai thitung $>\mathrm{t}$ tabel atau $(7,568>2,006)$. Dengan demikian hipotesis pertama yang diajukan bahwa terdapat berpengaruh signifikan antara disiplin terhadap kinerja kepala sekolah diterima.

\section{Pengaruh Iklim kerja Terhadap Kinerja Kepala sekolah}

Iklim kerja berpengaruh signifikan terhadap kinerja kepala sekolah dengan korelasi sebesar 0,663 atau memiliki hubungan yang kuat dengan kontribusi pengaruh sebesar 44,0\%. Pengujian hipotesis diperoleh nilai t hitung $>t$ tabel atau $(6,456>2,006)$. Dengan demikian hipotesis kedua yang diajukan bahwa terdapat berpengaruh signifikan antara iklim kerja terhadap kinerja kepala sekolah diterima.

\section{Pengaruh Disiplin dan Iklim kerja Terhadap Kinerja Kepala sekolah}

Disiplin dan iklim kerja berpengaruh signifikan terhadap kinerja kepala sekolah dengan diperoleh persamaan regresi $Y=7,924+0,419 \mathrm{X} 1+0,387 \mathrm{X} 2$, nilai korelasi sebesar 0,785 atau memiliki hubungan yang kuat dengan kontribusi pengaruh sebesar $61,6 \%$ sedangkan sisanya sebesar 38,4\% dipengaruhi faktor lain. Pengujian hipotesis diperoleh nilai $\mathrm{F}$ hitung $>\mathrm{F}$ tabel atau $(41,741>2,780)$. Dengan demikian hipotesis ketiga yang diajukan bahwa terdapat berpengaruh signifikan antara disiplin dan iklim kerja terhadap kinerja kepala sekolah diterima.

\section{SIMPULAN}

Disiplin berpengaruh signifikan terhadap kinerja kepala sekolah dengan kontribusi pengaruh sebesar 51,9\%. Uji hipotesis diperoleh nilai t hitung $>t$ tabel atau $(7,568>2,006)$. Iklim 
Hendrian Yonata, Hadion Wijoyo, \& Denok Sunarsi, Pengaruh Disiplin dan Iklim Kerja Terhadap Kinerja

kerja berpengaruh signifikan terhadap kinerja kepala sekolah dengan kontribusi pengaruh sebesar 44,0\%. Uji hipotesis diperoleh nilai t hitung > t tabel atau $(6,456>2,006)$. Disiplin dan iklim kerja berpengaruh signifikan terhadap kinerja kepala sekolah dengan kontribusi pengaruh sebesar $61,6 \%$ sedangkan sisanya sebesar 38,4\% dipengaruhi faktor lain. Uji hipotesis diperoleh nilai $\mathrm{F}$ hitung $>\mathrm{F}$ tabel atau $(41,741>2,780)$.

\section{DAFTAR PUSTAKA}

Agusta, L., \& Sutanto, E. (2013). Pengaruh Pelatihan Dan Motivasi Kerja Terhadap Kinerja Karyawan Cv Haragon Surabaya. Agora, 1(3), 1399-1408.

Andrianto, S., \& Wijoyo, H. (2020). Rancang Bangun Sistem Informasi Siswa Berbasis Web di Sekolah Minggu Buddha Vihara Dharmaloka Pekanbaru. TIN : Terapan Informatika Nusantara, 1(2), 83-90.

Latief, A., Nurlina, N., Medagri, E., \& Suharyanto, A. (2019). Pengaruh Manajemen Pengetahuan, Keterampilan dan Sikap terhadap Kinerja Karyawan. JUPIIS: Jurnal Pendidikan Ilmu-Ilmu Sosial, 11(2), 173-182. doi:https://doi.org/10.24114/jupiis.v11i2.12608Philipus, S. (2009). Analisis Faktor-faktor yang Mempengaruhi Kinerja Karyawan pada PT. Bumakumawa di Kota Sorong. Jurnal Ekonomi, 6(2), 176182. https://doi.org/ISSN :1693-0827

Latief, A. Rosalina, D. \& Apiska, D. (2019). Analisis Hubungan Antar Manusia terhadap Kinerja Karyawan. Journal of Education, Humaniora and Social Sciences (JEHSS). 1 (3): 127-131.

Haryati, E., Suharyanto, A. Hasmayni, B. \& Siregar, F.H. (2019). The Effect of Work Environment and Work Stress on Employee Performance at PT Aneka Gas Industri Tbk Research Article in Proceedings of the 2nd International Conference on Social Sciences and Interdisciplinary Studies (formerly ICCSSIS), ICCSIS 2019, 24-25 October 2019, Medan, North Sumatera, Indonesia

Soepeno, D., Taroreh, R., \& Sumaki, W. (2015). Pengaruh disiplin kerja, budaya organisasi, dan komunikasi terhadap kinerja karyawan pt. Pln (persero) wilayah suluttenggo area manado. Jurnal berkala ilmiah efisiensi, 15(5). https://doi.org/10.35794/emba.v3i3.10129

Suci, I. G. S., Indrawan, I., Wijoyo, H., \& Kurniawan, F. (2020). Transformasi Digital Dan Gaya Belajar (Vol. 1, Issue 1).

Sunarsi, D., Wijoyo, H., Prasada, D., \& Andi, D. (2020). Pengaruh lingkungan kerja terhadap kinerja karyawan pada pt. Mentari persada di jakarta. In Seminar Nasional Manajemen (Vol. 5, Issue 1).

Wahyuningtyas, S., \& Utami, H. N. (2018). Analisis Perbedaan Kinerja Karyawan Outsourcing Dan Karyawan Tetap ( Studi Pada Karyawan Bank BRI Kantor Cabang Malang Kawi ). Ilmu Administrasi, 60(3), 96103.

Wijoyo, H. (2009). Motivasi dan Komitmen Organisasi Sebagai Variabel Moderating Dalam Hubungan Antara Partisipasi Penyusunan Anggaran dan Kinerja Manajerial (Studi Empiris pada Perusahaan yang Terdaftar sebagai Anggota Asosasi Aspal Beton (AABI) di Pekanbaru. In Jurnal Ilmiah Ekonomi dan Bisnis: Vol. (Issue). 